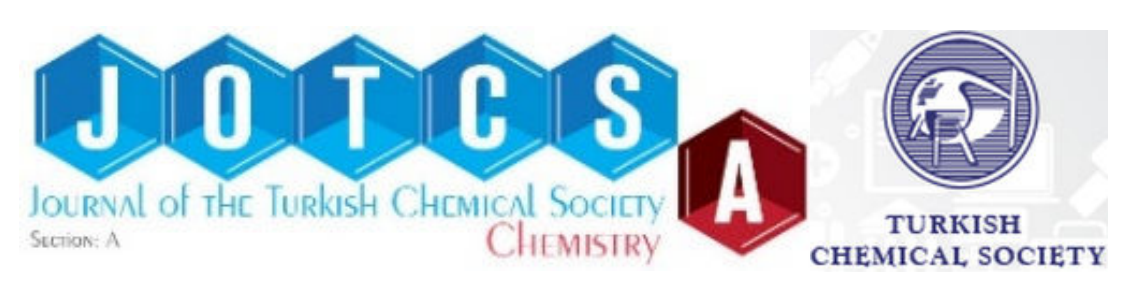

(This article was presented to the 28th National Chemistry Congress and submitted to JOTCSA as a full manuscript)

\title{
In Vitro Studies on Pesticide-Induced Oxidative DNA Damage
}

\author{
Özlem DEMİRCI ${ }^{1}$, Bircan ÇEKEN TOPTANCI ${ }^{2}$ and Murat $\mathrm{KIZIL}^{2}$ \\ ${ }^{1}$ University of Dicle, Faculty of Science, Biology Department, 21280, Diyarbakır, Turkey \\ ${ }^{2}$ University of Dicle, Faculty of Science, Chemistry Department, 21280, Diyarbakır, \\ Turkey
}

\begin{abstract}
Pesticides are among the most extensively used chemicals in the world today and they are also among the most hazardous compounds for the human. This study was designed to use the plasmid relaxation assay to describe the association of markers of DNA damage with pesticide exposure. The DNA damage activity of fluoxastrobin and imazamox were checked on pBluescript M13+ plasmid DNA (3.2 kb) in the absence and presence of $\mathrm{Cu}(\mathrm{II})$ ions. It has been found that the fluoxastrobin and imazamox can cleavage plasmid DNA in the absence and presence of $\mathrm{Cu}(\mathrm{II})$ ions. DNA cleavage was found to be concentration- and time-dependent. In conclusion, the present study showed that fluoxastrobin and imazamox can damage DNA, which warrants for further investigations to correctly evaluate the hazards of exposure to these chemicals.
\end{abstract}

Keywords: DNA damage; Genotoxicity; Fluoxastrobin; Imazamox.

Submitted: July 17, 2016. Revised: September 09, 2016. Accepted: October 06, 2016.

Cite this: Demirci Ö, Çeken Toptancı B, Kızıl M. In Vitro Studies on Pesticide-Induced Oxidative DNA Damage. JOTCSA. 2016;3(3):479-90.

DOI: $10.18596 /$ jotcsa.67098.

*Corresponding author. E-mail: ozdem22@gmail.com. 


\section{INTRODUCTION}

Though extreme anthropogenic activities bring about innumerable accumulation of xenobiotics in biosphere $(1,2)$, especially pesticides are designed specifically to kill the organisms. Therefore, they are one of the most dangerous chemical compounds (3). Pesticides have to comply with a demand: a high degree of toxicity for only target organisms, but synthetic pesticides are quite inadequate in this respect (4). Pesticides consist of a heterogeneous class of chemicals, developed for the purpose of controlling pests, requisite in modern agriculture, but numerous studies available in the literature are with regard to their genotoxicity (5).

The primary risk factor is the genotoxic potential for long-term effects such as carcinogenic and reproductive toxicology. Most of the pesticides have been tried in a wide range of mutagenicity assays covering gene mutation, DNA damage and chromosomal alteration (6).

Fluoxastrobin is a new strobilurin-type fungicide and it has a broad spectrum of activity against many fungal diseases. It is known that Fluoxastrobin has been registered for foliar utilization on corn vegetables, peanuts, and tuberous, fruiting vegetables, leaf petiole vegetables, and turf, as well as peanut.

Imazamox is a widely used herbicide in the imidazolinone herbicide family and inhibits the acetolactate synthase enzyme, which is critical for the synthesis of the amino acids valine, leucine, and isoleucine in plants.

In field crops, imazamox is effective against a large variety of grass and broadleaf weeds, including downy brome, red rice, shattercanech, jointed goatgrass, wild mustards, common ragweed, common lambsquarters, and others. Pesticides tend to accumulate in the environment and organisms.

It was reported that the amount of pesticide utilized was approximately 2.4 million tons in both 2006 and 2007, with herbicides calculating for the largest part of the total use, followed by other pesticides, fungicides, and insecticides (7). Distinct agriculture applications practised in agricultural areas of the extensive farming inside of hothouses (most especially close the seaboard) and another hand conventional agriculture, which accounts for a heterogeneous type of pesticide use (8). 
Pesticides can be connected to each groove of the DNA double helix with various noncovalent interactions. For example; pesticides can be linked in the wall/surface of each groove of DNA with hydrophobic interaction, specific hydrogen bonds or van der Waals interactions.

Experimental input demonstrated that numerous pesticides had mutagenic qualities causing genetical chromosomal alteration, DNA damage, or mutation (9).

Pesticides exposure caused increasing incidence of cancer, endocrine disorders, neurodegenerative disorders, birth defects, reproductive disorders, Parkinson, Alzheimer, diabetes, cardiovascular diseases, chronic nephropathies, and chronic respiratory disease (10).

However, few in vitro studies focusing on effects of pesticides on DNA damage have been performed. A study of the genotoxicity of chemicals, such as fluoxastrobin and imazamox is important because of their possible consequences on human health and their relation with cancer and other diseases. Therefore, the aim of present study was to determine the effect of fluoxastrobin and imazamox on plasmid DNA in the absence and presence of ions $\mathrm{Cu}(\mathrm{II})$ ions.

\section{MATERIALS AND METHODS}

\section{Chemicals}

Fluoxastrobin, Imazamox, acetone, agarose, bromophenol blue, copper(II) chloride, sodium chloride, ethylenediaminetetraacetic acid (EDTA), glacial acetic acid, and trisma base were purchased from Sigma-Aldrich (St Louis, MO) and ethidium bromide was obtained from Amresco LLC (Solon, $\mathrm{OH}$ ). Plasmid miniprep kit was obtained from Qiagene (Valencia, CA).

\section{Purification of Plasmid DNA}

Genejet plasmid mini preparation kit was used to isolate the pBluescript M13+ plasmid DNA. U.V spectroscopy was used to checked the purity of plasmid DNA. DNA concentration is estimated by measuring the absorbance at $260 \mathrm{~nm}$. $\left(A_{260}=1.0\right.$ for $\left.50 \mu \mathrm{g} / \mathrm{mL}\right)$. 


\section{DNA Damage with Fluoxastrobin and Imazamox}

This study was designed to use the plasmid relaxation assay to describe the association of markers of DNA damage with pesticide exposure (11). DNA cleavege activity of fluoxastrobin and imazamox were checked in the absence and presence of $\mathrm{Cu}$ (II) ions on pBluescript M13+ plasmid DNA (3.2 kb) by agarose gel electrophoresis according to Çeken (12).

0.5-mL Eppendorf tubes which were covered with aluminum foil were used for the reactions and for protecting the samples from light. All reactions were performed in a volume of 10 $\mu \mathrm{L}$, containing $200 \mathrm{ng}$ of pBluescript M13+ plasmid DNA at room temperature, in phosphate buffer ( $\mathrm{pH} 7.4 ; 14.29 \mathrm{mM} \mathrm{NaCl}, 7.14 \mathrm{mM}$ phosphate). Fluoxastrobin and Imazamox (50, $100,150,200,250 \mu \mathrm{g} / \mathrm{mL}$ ) were added in the absence and presence of (II) at a final concentration of $100 \mu \mathrm{M}$. Electrophoresis was performed in the presence of ethidium bromide $(10 \mathrm{mg} / \mathrm{mL})$, at $60 \mathrm{~V}$ for 90 minutes.

In this experiment, we take advantage of the fact that double-stranded plasmid DNA molecules generally exhibit three conformations that reflect the integrity of the DNA: Supercoiled (sc), open circular (oc), and linear (I).

\section{Densitometric analysis}

Gel documentation system was used for scanning to the gel (Gel-Doc-XR; BioRad).

\section{RESULTS AND DISCUSSION}

In order to assess whether prolonged exposure to pesticides in the presence of metal ions could lead to an increase in genetic damage, plasmid DNA exposed to pesticides were evaluated using plasmid relaxation assay.

Excessive use of pesticides in agricultural or domestic areas results in environmental contamination. Though pesticides have significant contributions for the elimination of the harmful effects of pests on plant, animal, and human, they have toxic effects on the nontarget organism. 
It has been clearly demonstrated that pesticidal toxicity alters a variety of physiological functions. Additionally, evidence has shown that pesticide exposure can promote the risk of neurodegenerative diseases and cancer.

Recent evidence also suggests that the pesticides which act as endocrine disruptors have the ability to cause diverse side effect regarded to developmental toxicity and reproductive.

Therefore, it is now evident that research towards understanding how pesticides effect the progression and development of disease will cause to further improvements in public health.

In the literature, chlorpyrifos, methyl parathion, and malathion were investigated for their DNA damage activities $(13,14)$. However, there is no study with new generation pesticides. Therefore, in this study we used the plasmid relaxation assay to describe the association of markers of DNA damage with fluoxastrobin and imazamox exposure. Plasmid relaxation assay is a cheap and fast method to explain the toxic effect of pesticide. Oxidative damage to DNA is one of the most important mechanisms in the initiation of cancer such damage is sometimes caused by pesticides.

This study is the first to investigate the role of metal ion (copper) in the observed toxic action of pesticides. It is known that copper has the ability to capable of mediating the action of several phenolic compounds producing reactive oxygen and other radicals (15). Since copper exists in the nucleus and is closely associated with chromosomes and DNA bases, in this study we have investigated whether the activation of pesticides such as fluoxastrobin and imazamox by copper can induce strand breaks in DNA. Copper salts have been used extensively as fungicides for a long time so that it is very important to investigate the effects of the combination of copper with other pesticides (16).

The role of fluoxastrobin and imazamox DNA damage was evaluated, and the exposure time is presented in Figure 1-4. As shown in Figures 1 and 3, fluoxastrobin at concentrations between $50-250 \mu \mathrm{g} / \mathrm{mL}$ has no significant effect on cleavage of plasmid DNA in the absence and presence of $\mathrm{Cu}$ (II) ions (Figure 1, lane 2-6; Fig 3, lane 3-7). On the other hand, at the concentration between $50-250 \mu \mathrm{g} / \mathrm{mL}$ imazamox can effectively promote cleavage of plasmid DNA in the absence and presence of $\mathrm{Cu}$ (II) ions (Figure 2, lane 2-6; Fig 4, lane 3-7). 
In the presence of $100 \mu \mathrm{M}$ concentration of $\mathrm{Cu}(\mathrm{II})$, imazamox $(50-250 \mu \mathrm{g} / \mathrm{mL})$ induced extensive DNA strand breaks as indicated by disappearance of supercoiled (sc) form and the formation of open circular (oc) and linear form (I).

Copper is widely distributed in nature and is an essential element. Acute poisoning occurs most frequently from the ingestion of copper sulfate or other copper salts, and hepatic necrosis is characteristic of copper poisoning. The redox properties of copper and iron complexes of adriamycin, bleomycin, and thiosemicarbazones have been investigated by electron spin resonance spectroscopy (ESR) (17).

A common property of these metal complexes is their ability to be readily reduced by thiol compounds and oxidized by iron or reduced species of iron to produce free radicals. Copper is also a common cofactor for many enzymes including oxidases and oxygenases (18). Similar to iron, copper acts as a catalyst in the formation of reactive oxygen species and catalyzes peroxidation of membrane lipids (19). The metal ions present in some pesticides and fertilizers (20) may interfere with DNA repair and produce reactive oxygen species (ROS), leading to oxidative damage (6). The pesticide-metal ion-DNA associations might contribute to genotoxicity.

The individual and the combined toxicity of pesticides and metals were studied by Bhuvaneshwari et al. (2012). They observed that pesticides, metal ions, and a mixture of them caused DNA damage and this damage inducts mutation in the GADD45 $\beta$ gene (21).

The cleavage of DNA was found to depend on both the concentration of pesticide and the reaction time (24-48 h). Our results indicate that both pesticides used in this study have the ability to damage plasmid DNA in the absence and the presence of metal ions. Therefore, further detailed evaluation of genotoxicity is thus required. 


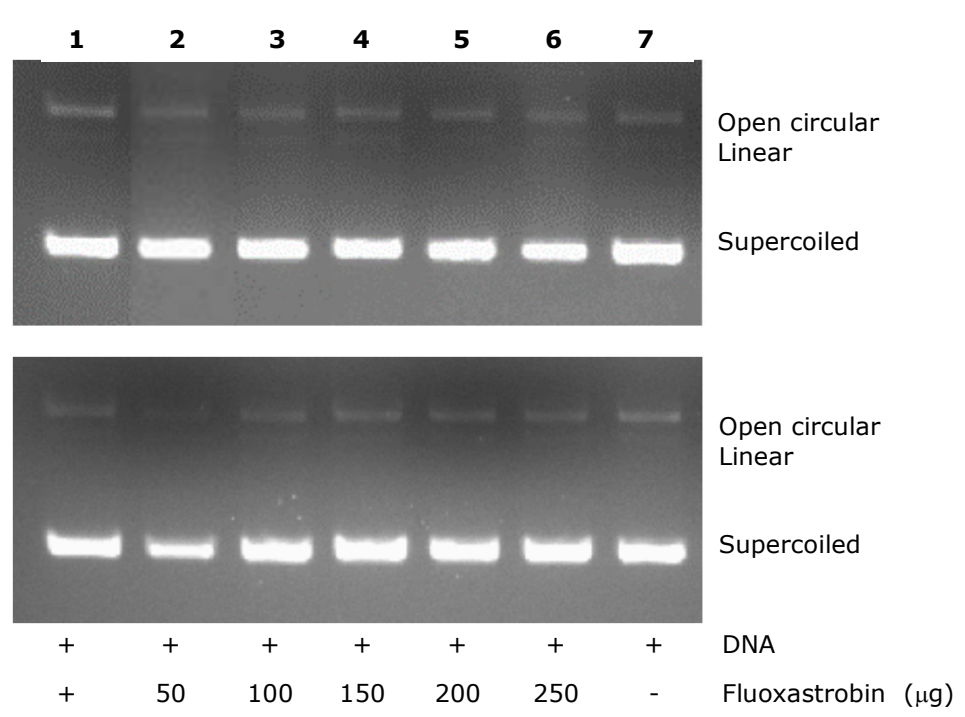

Figure 1. Gel electrophoresis diagram showing the cleavage of pBluescript M13+ plasmid DNA (3.2 kb) fluoxastrobin in the dark at different exposure times (A: $24 \mathrm{~h}, \mathrm{~B}: 48 \mathrm{~h})$.

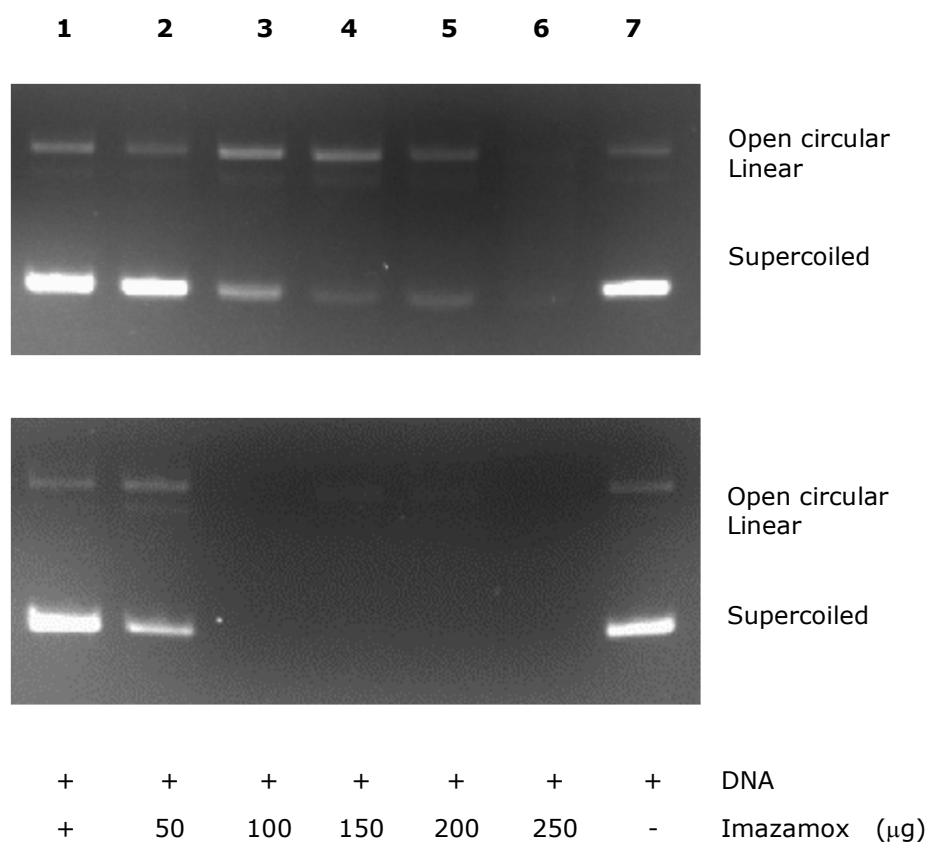

Figure 2. Gel electrophoresis diagram showing cleavage of pBluescript M13+ plasmid DNA ( $3.2 \mathrm{~kb})$ by imazamox in the dark at different exposure times ( $A: 24 \mathrm{~h}, \mathrm{~B}: 48 \mathrm{~h}$ ). 

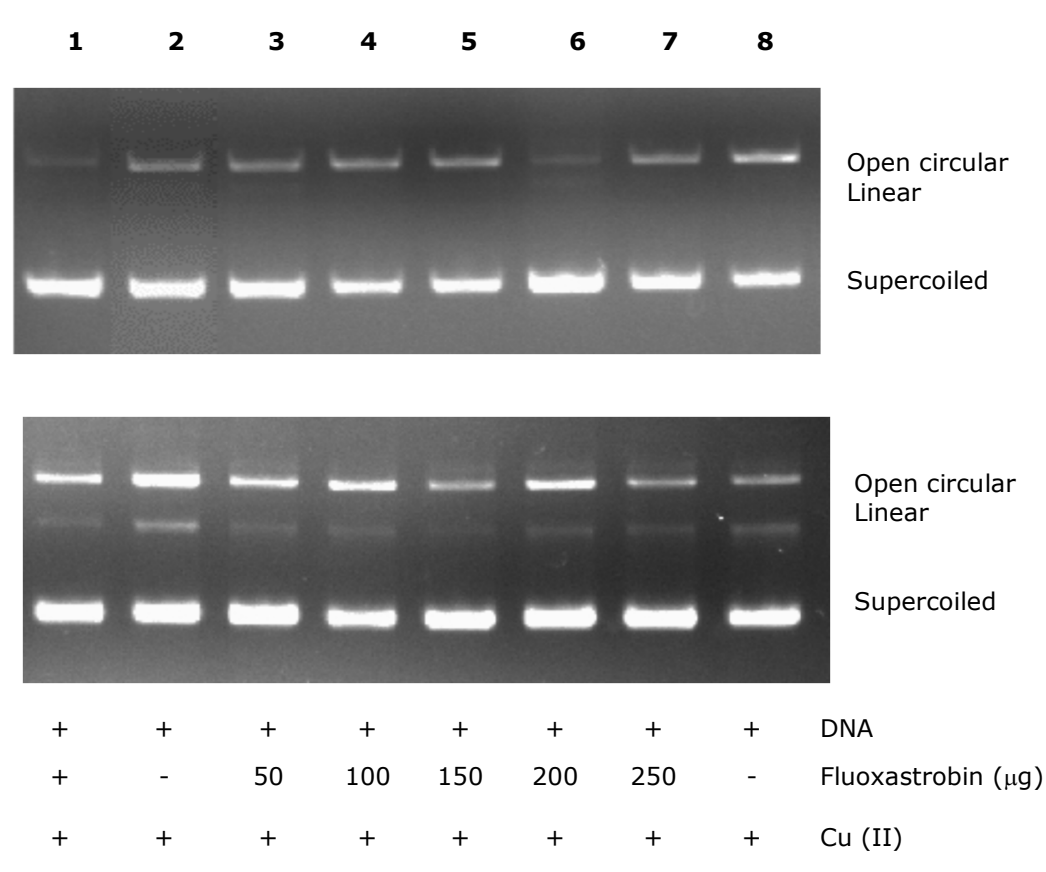

Figure 3. Gel electrophoresis diagram showing cleavage of pBluescript M13+ plasmid DNA $(3.2 \mathrm{~kb})$ by fluoxastrobin in the presence of $\mathrm{CuCl}_{2}$ in the dark at different exposure times (A: 24h, B: $48 \mathrm{~h}$ ).
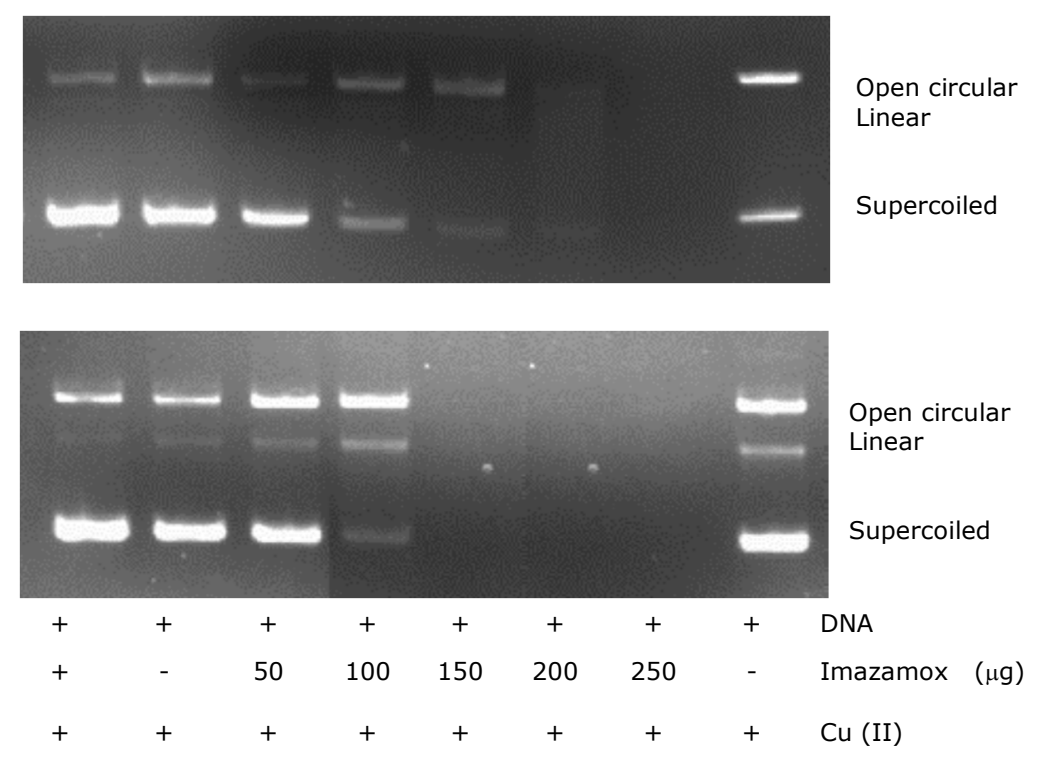

Figure 4. Gel electrophoresis diagram showing cleavage of pBluescript $\mathrm{M} 13+$ plasmid DNA (3.2 kb) by imazamox in the presence of $\mathrm{CuCl}_{2}$ in dark at different exposure times (A: 24h, B: $48 \mathrm{~h})$. 


\section{REFERENCES}

1. Fernández-Alba AR, Guil H, López GD, Chisti Y. Comparative evaluation of the effects of pesticides in acute toxicity luminescence bioassays. Analytica Chimica Acta. 2002;451:195-202. DOI: $10.1016 / S 0003-2670(01) 01422-2$.

2. Vrankovic J, Labus-Blagojevic S, Csanyi B, Makovinska J, Cvetkovic O, Gacic Z, et al. Antioxidant enzymes and GST activity in natural populations of Holandriana holandrii from the Bosna River. Turkish Journal of Biology. 2012;36:477-85. DOI: 10.3906/biy-1111-43.

3. Hanazato T. Pesticide effects on freshwater zooplankton: an ecological perspective. Environmental Pollution. 2001;112:1-10. DOI: 10.1016/S0269-7491(00)00110-X.

4. Lioi MB, Scarfi MR, Santoro A, Barbieri R, Zeni O, Di Berardino D, et al. Genotoxicity and oxidative stress induced by pesticide exposure in bovine lymphocyte cultures in vitro. Mutation Research/Genetic Toxicology and Environmental Mutagenesis. 1998403 13-20. DOI: 10.1016/S0027-5107(98)00010-4.

5. Fragiorge EJ, Rezende AAAd, Graf U, Spanó MA. Comparative genotoxicity evaluation of imidazolinone herbicides in somatic cells of Drosophila melanogaster. Food and Chemical Toxicology. 2008;46(1):393-401. DOI: 10.1016/j.fct.2007.08.022.

6. Bolognesi C. Genotoxicity of pesticides: a review of human biomonitoring studies. Mutation Research/Reviews in Mutation Research. 2003;543(3):251-72. DOI: 10.1016/S13835742(03)00015-2.

7. Grube A, Donaldson D, Kiely T, Wu L. U.S. EPA Pesticide Market Estimates: 2006-2007. Office of Pesticide Programs. Washington, DC 2011. URL: https://www.epa.gov/sites/production/files/2015-10/documents/market_estimates2007.pdf. 
8. Parrón T, Requena M, Hernández AF, Alarcón R. Association between environmental exposure to pesticides and neurodegenerative diseases. Toxicology and Applied Pharmacology. 2011 256:379-85. DOI: 10.1016/j.taap.2011.05.006.

9. Bolognesi C, Morasso G. Genotoxicity of pesticides: potential risk for consumers. Trends in Food Science \& Technology 2000;11:182-7. DOI: 10.1016/S0924-2244(00)00060-1.

10. Mostafalou S, Abdollahi M. Pesticides and human chronic diseases: Evidences, mechanisms, and perspectives. Toxicology and Applied Pharmacology. 2013;268(2):157-77. 10.1016/j.taap.2013.01.025.

11. Çeken B, Kízíl M. Synthesis and DNA-cleaving activity of a series of substituted arenediazonium ions. Russian Journal of Bioorganic Chemistry. 2008;34(4):488-98. DOI: $10.2307 / 3752354$.

12. Toptancı BÇ. (+)-Duocarmycin Antibiyotiği Analoglarının Sentezlenmesi ve DNA Üzerine Etkilerinin Araştırılması. Dicle University, Science Faculty, Chemistry Department. [PhD Thesis]. 2013.

13. Bagchi D, Bagchi M, Hassoun E, Stohs S. In vitro and in vivo generation of reactive oxygen species, DNA damage and lactate dehydrogenase leakage by selected pesticides. Toxicology. 1995;104(1):129-40. DOI: 10.1016/0300-483X(95)03156-A.

14. Ojha A, Yaduvanshi SK, Pant SC, Lomash V, Srivastava N. Evaluation of DNA damage and cytotoxicity induced by three commonly used organophosphate pesticides individually and in mixture, in rat tissues. Environmental Toxicology. 2013;28(10):543-52. DOI: 10.1002/tox.20748.

15. Nazeem S, Azmi AS, Hanif S, Kumar KS. Reactive Oxygen-Dependent DNA Damage Resulting from the Oxidation of Plumbagin by a Copper-redox Cycle Mechanism: Implications for its Anticancer Properties. Austral-Asian Journal of Cancer. 2008;7:65-72. URL: http://cancerres.aacrjournals.org/content/54/7 Supplement/1895s.short. 
16. Chester F. The copper salts as fungicides. The Journal of Mycology. 1890:21-4. DOI: $10.2307 / 3752354$.

17. Antholine WE, Kalyanaraman B, Petering DH. ESR of copper and iron complexes with antitumor and cytotoxic properties. Environmental Health Perspectives. 1985;64:19. URL: https://www.ncbi.nlm.nih.gov/pmc/articles/PMC1568621/.

18. Gutteridge J. Tissue damage by oxy-radicals: the possible involvement of iron and copper complexes. Medical biology. 1983;62(2):101-4. URL:

http://europepmc.org/abstract/med/6471925.

19. Chan PC, Peller OG, Kesner L. Copper (II)-catalyzed lipid peroxidation in liposomes and erythrocyte membranes. Lipids. 1982;17(5):331-7. DOI: 10.1007/BF02535190.

20. Zoffoli HJO, do Amaral-Sobrinho NMB, Zonta E, Luisi MV, Marcon G, Tolón-Becerra A. Inputs of heavy metals due to agrochemical use in tobacco fields in Brazil's Southern Region. Environmental Monitoring and Assessment. 2013;185(3):2423-37. DOI: 10.1007/s10661-012$2721-y$.

21. Bhuvaneshwari R, Babu Rajendran R, Kumar K. Induction of DNA Damage and GADD45 $\beta$ gene Mutation in Zebra fish (Danio rerio) due to Environmentally Relevant Concentrations of Organochlorine Pesticides \& Heavy Metals. International Journal of Environmental Research. 2012;7(1):219-24. URL: https://ijer.ut.ac.ir/article_600_7.html. 


\title{
Türkçe Öz ve Anahtar Kelimeler
}

\section{Pestisit-Kaynaklı Oksidatif DNA Hasarı üzerine in vitro Çalışmalar}

\author{
Özlem DEMİRCİ, Bircan ÇEKEN TOPTANCI ve Murat KIZIL
}

Öz: Pestisitler dünyada bugün en çok miktarda kullanılan kimyasallar arasında olup insanlar için en zararlı bileşikleri oluşturmaktadır. Bu çalışma, pestiside maruz kalmakla beraber DNA hasarını gösteren işaretlerin toplamını tarif etmek üzere plazmid gevşeme çalışmasını kullanmaktadır. Fluoksastrobin ve imazamox pestisitlerinin DNA hasar aktivitesi pBluescript $\mathrm{M} 13+$ plazmid DNA $(3,2 \mathrm{~kb})$ incelemesi $\mathrm{Cu}(\mathrm{II})$ iyonlarının varlığında ve yokluğunda incelenmiştir. Fluoksastrobin ve imazamox'un plazmid DNA'sını Cu(II) iyonlarının varlığında ve yokluğunda parçalayabildiği bulunmuştur. DNA parçalanmasının derişime ve zamana bağlı olduğu bulunmuştur. Sonuç olarak, bu çalışma fluoksastrobin ve imazamox'un DNA'yı tahrip edebildiğini göstermiştir, bu da söz konusu kimyasalların maruziyetleri için zararlı etkinin doğru bir şekilde değerlendirilmesi için daha fazla çalışma yapılması gerektiğini göstermektedir.

Anahtar kelimeler: DNA hasarı; Genotoksisite; Fluoksastrobin; Imazamox.

Gönderilme: 17 Temmuz 2016. Düzeltme: 09 Eylül 2016. Kabul: 06 Ekim 2016. 